\section{Aquaculture}

Volume 265, Issues 1-4, 1 May 2007, Pages 102-108

http://dx.doi.org/10.1016/j.aquaculture.2006.10.029

(c) 2007 Published by Elsevier B.V.
Archimer, archive institutionnelle de l'ffremer http://www.ifremer.fr/docelec/

\title{
Genetic investigation of swimbladder inflation anomalies in the European sea bass, Dicentrarchus labrax L.
}

\author{
Stefano Peruzzi $i^{a,{ }^{*}}$, Jon-Ivar Westgaard ${ }^{\mathrm{a}}$ and Béatrice Chatain ${ }^{\mathrm{b}}$

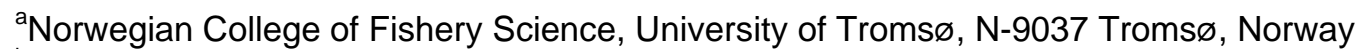 \\ ${ }^{\mathrm{b}}$ IFREMER, Laboratoire de Recherche Piscicole de Méditerranée, Chemin de Maguelone, F-34250 \\ Palavas-les-Flots, France \\ *: Corresponding author : stefanop@nfh.uit.no
}

\begin{abstract}
:
Although the aetiology of swimbladder inflation anomalies in important aquaculture species such as European sea bass $D$. labrax is not fully determined, culture conditions are commonly suggested as main contributory factors. Little information is available on whether swimbladder inflation has a genetic basis for its expression too. In this work, 24 full-sibling sea bass families from a 4 dams $\times 6$ sires factorial crossing were reared under communal conditions. The larvae developing normal and abnormal (uninflated or hyper-inflated) swimbladders were genotyped at four microsatellite loci, Labrax-3, Labrax-13, Labrax-17, Labrax-29, and allocated to the individual breeders. Out of 273 offspring, $97 \%$ could be assigned to a single parental pair. The genotype and pedigree analysis showed an imbalance in family size due to differential survival of larvae with normally inflated swimbladders, with the offspring generated from one dam and one sire being two- to three-fold superior to the other parents, respectively. In larvae with non-inflated swimbladder, significant differences in family size were observed only among half-sibling sire families, whereas in larvae with hyper-inflated swimbladder such differences were found both among half-sibling sire and dam families. The results suggest that paternally and maternally inherited factors may contribute to the expression of swimbladder anomalies in sea bass along with major environmental clues.
\end{abstract}

Keywords: Swimbladder; Anomalies; Genetics; Sea bass; Dicentrarchus labrax 


\section{Introduction}

The swimbladder of fishes is a hydrostatic, buoyancy-regulating organ which develops during early larval ontogeny from the dorsal wall of the digestive tract. It also plays a role in the perception and production of sounds as well as in respiratory processes. The swimbladder may inflate either through the transfer of atmospheric air via a pneumatic duct, as in physostomous fish, or by internal gas diffusion like in physoclist fish, or some combination of both (Alexander, 1966; Pelster, 1998). Some physoclist fish, which include the European sea bass (Dicentrarchus labrax), are transient physostomous as larvae, possessing a temporary pneumatic duct and seem to rely on the gulping of air at the water surface for the initial activation of the swimbladder (Chatain, 1986; Kitajima et al., 1994; Bailey and Doroshov, 1995). Although the mechanisms and conditions for functional swimbladder inflation achievement vary among fish, its initial inflation seems to take place during a particular and finite interval, generally associated to the critical time of transition from endogenous to exogenous feeding (Trotter et al., 2005).

Correct swimbladder inflation is essential for functional buoyancy control, swimming ability and feeding success. Failure to inflate the swimbladder has been regarded as a major obstacle in the rearing of important commercial species such as striped bass, Morone saxatilis (Martin-Robichaud and Peterson, 1998), sea bream, Sparus auratus, and European sea bass (Chatain, 1994). Fish lacking a functional swimbladder have been reported to show higher mortality (Chatain, 1986, 1987; Chapman et al., 1988a; Chatain and Dewavrin, 1989; Trotter et al., 2003), increased metabolic rate (Marty et al., 1995), delayed growth (Battaglene and Talbot, 1992; Crespo et al., 2001; 
51 Jacquemond, 2004) and skeletal deformities (Chatain, 1994; Kitajima et al., 1994; Divanach et al.,

52 1997; Jacquemond, 2004; Trotter et al., 2001). The rate of swimbladder inflation in some

53 physostome and transient physostome larvae has been significantly improved by use of surface

54 cleaning devices favouring access to the air-water interface (Chatain and Ounais-Guschemann, 1990). However, since other factors like tank hydrodynamics, light intensity, salinity, and temperature may contribute to hamper or preclude swimbladder inflation in these fish, specific sets of environmental variables are often required (Divanach et al., 1996). On the whole, as fish with uninflated swimbladders are useless for commercial purposes, early methods for detecting and separating them from normal fish have been developed in important hatchery-reared species

60 (Chapman et al., 1988b; Chatain and Corrao, 1992; Jacquemond, 2004). Phenomena of hyper61 inflation or hypertrophy of the swimbladder during larval stages are little investigated despite being 62 known to cause considerable losses under unfavourable culture conditions in some species 63 (Bagarinao and Kungvankij, 1986; Planas and Cunha, 1999).

Although the biotic and abiotic mechanisms capable of influencing initial swimbladder inflation in fish may be quite numerous, the environmental/culture conditions are generally regarded as main contributory factors (Zilberg et al., 2004). In contrast, little attention has been devoted so far to see whether the process of swimbladder inflation has a genetic basis for its expression too (Harrell et al., 2002; Zilberg et al., 2004).

The present work was undertaken in order to investigate possible parental effects on swimbladder inflation anomalies (non-inflation and hyper-inflation) observed in hatchery-reared sea

71 bass larvae. For this purpose, we performed a genotype and pedigree analysis of sibling families originating from a full factorial crossing and maintained under communal rearing conditions. 


\section{Material and methods}

\subsection{Fish}

Fish originated from a commercial sea bass broodstock held under natural conditions of photoperiod and temperature and spawned following a previously published protocol (Peruzzi and Chatain, 2000). A total of $n=10$ mature females received a single injection of Luteinizing Hormone Releasing Hormone (LHRHa) at $10 \mu \mathrm{g} \mathrm{kg}$-1 body weight. Mature oocytes were obtained from 8 out of 10 females approximately 72 hours following hormonal injection. Eggs of individual dams were equally divided into 6 aliquots of $50 \mathrm{ml}$ and each aliquot was fertilized with $0.5 \mathrm{ml}$ of sperm drawn from a single male ( $n=6)$ according to a full-factorial mating design producing 48 full-sibling families (8 dams x 6 sires). Individual families were maintained in 12l cylindro-conical incubators placed in a thermo-regulated seawater system at $13^{\circ} \mathrm{C}$ (Saillant et al., 2001). Floating (alive) and sinking (dead) eggs were separated at embryonation (48 hours post-fertilization) by increasing the salinity to $40 \%$ and their total volume and estimated number measured following the method described by Chatain (1994). Only 24 families (4 dams x 6 sires) generated enough living eggs for the requirements of the experiment. Equal aliquots of embryonated eggs ( $5 \mathrm{ml}$ or approx. 5000 eggs) were sampled from these families, pooled, transferred into a $500 \mathrm{l}$ tank maintained at $13-14^{\circ} \mathrm{C}$ until 20 days post-hatching (dph) and then at $20^{\circ} \mathrm{C}$ following standard rearing procedures for sea bass (Peruzzi et al., 2004). Water quality was monitored by a daily control of temperature and salinity, and weekly check of oxygen level, $\mathrm{pH}, \mathrm{NH}_{3}, \mathrm{NH}_{4}{ }^{+}, \mathrm{NO}_{2}{ }^{-}$, and $\mathrm{NO}_{3}{ }^{-}$concentrations.

\subsection{Sampling}

Measurement of larvae $\left(L_{\mathrm{T}}, \mathrm{mm}\right)$ and verification of swimbladder condition were performed using a profile projector (Nikon V12), while photographs were taken using a Zeiss microscope fitted with a video camera module (Visilog 5.2 @Noesis Vision, Canada). Larvae with hyperinflated swimbladder were collected $(n=100)$ from the surface of the tank between 15 and 25 dph. Larvae with normal and without functional swimbladder were sorted following the method described by 
102 Chatain and Corrao (1992) at the end of the larval period (45 dph). They were counted by a 103 photographical method (Chatain et al., 1996), sampled ( $n=100$ /group) and finally preserved in 95\% 104 ethyl alcohol for further genotyping.

\subsection{Molecular analyses and parental assignments}

Nuclear DNA was extracted by alkaline lysis from portions of ethanol preserved larvae (Saillant et al., 2002). Briefly, alcohol was allowed to evaporate at ambient temperature in an Eppendorf tube and the dry tissue lysed in $\mathrm{NaOH} 200 \mathrm{mM}\left(3 \mathrm{hr}, 55^{\circ} \mathrm{C}\right)$. The solution was then neutralized with tris$\mathrm{HCl} 200 \mathrm{mM}$ and $\mathrm{pH}$ adjusted to 8.

111 The primers of five polymorphic microsatellite loci, Labrax-3, Labrax-13, Labrax-17, Labrax-29

112 (Garcia de Leon et al., 1995) and Dla-22F (Ciftci et al., 2002) were amplified by PCR. The general 113 PCR protocol was: 50-100 ng DNA, 0.1-1.0 $\mu \mathrm{M}$ primer, $400 \mu \mathrm{M}$ dNTP, $10 \mathrm{mM}$ Tris-HCl, $50 \mathrm{mM}$ $114 \mathrm{KCl}, 1.5 \mathrm{mM} \mathrm{MgCl}_{2}$, and $0.5 \mathrm{U}$ taq polymerase (AB gene). The PCR reactions were carried out on a 115 GeneAmp 2700 thermal cycler (Applied Biosystems) using the following profile: $94^{\circ} \mathrm{C}$ for $10 \mathrm{~min}$, 116 followed by 37 cycles of $94^{\circ} \mathrm{C}$ for $20 \mathrm{~s}, 59^{\circ} \mathrm{C}$ for $30 \mathrm{~s}$ and $72^{\circ} \mathrm{C}$ for $60 \mathrm{~s}$, with a final extension of $11772^{\circ} \mathrm{C}$ for $10 \mathrm{~min}$. Forward primers were labelled with fluorescent dyes. The PCR products were 118 separated by electrophoresis using an ABIPrism ${ }^{\circledR} 3100$ Genetic Analyzer for fluorescent-labelled 119 products (Applied Biosystems). Alleles were scored using a GeneMapper ${ }^{\circledR}$ Software v3.7 package 120 (Applied Biosystems).

\subsection{Statistical analysis}

Based on the microsatellite genotypes from the parents and offspring potential parent pairs were explored among the offspring by means of likelihood-based parental allocation using the software

PAPA 1.1 (Duchesne et al., 2002). The allocation method implemented in this software is based on breeding likelihood (Sancristobal and Chevalet, 1997). Given an offspring genotype, the likelihood 
127 of a parental pair of genotypes is defined as the probability of this pair breeding the offspring 128 genotype among all of its possible descents.

129 Data concerning the swimbladder status were analyzed by contingency table analysis using $\chi^{2}$ 130 (Dagnelie, 1975). For normally-inflated fish $\left(\mathrm{S}^{+}\right)$, the observed $(O)$ frequencies were compared to 131 expected $(E)$ equal proportions of individuals in each family. For non-inflated (S`) and hyper132 inflated groups $\left(\mathrm{S}^{++}\right)$, the observed frequencies were compared to expected frequencies weighted for 133 the survival frequencies observed in normal fish $\left(\mathrm{S}^{+}\right)$and calculated as follows:

$$
E_{i}=O_{S^{+} i} N
$$

with $E_{i}$ being the expected frequency for the cell $i^{\underline{t h}}$ within a group, $N$ the total observations in that group, and $\mathrm{O}_{\mathrm{S}^{+}}$the corresponding observed frequency in the $\mathrm{S}^{+}{ }_{i}$ group.

Statistical analyses were performed using Statview ${ }^{\mathrm{TM}} \mathrm{SE}+$ software. Differences to the equilibrium were accepted as significant when $P<0.05$. All means were expressed as values $\pm 95 \%$ confidence interval (CI).

\section{Results}

Survival rate from the stage of embryonated eggs to 45 dph was $13 \%$. The percentage of larvae affected by hyperinflation could not be exactly estimated but was around $1 \%$ of the total fish. These larvae were recorded in a period between $15 \mathrm{dph}$ and $25 \mathrm{dph}$, and averaged $5.92 \pm 0.17 \mathrm{~mm}$ to 10.95 $\pm 0.46 \mathrm{~mm} L_{\mathrm{T}}$. The proportion of larvae with normally inflated and non-inflated swimbladder recorded at 45 dph was $97 \%$ and $3 \%$ respectively. At this stage, the mean length of the larvae was approximately $15.80 \pm 0.32 \mathrm{~mm} L_{\mathrm{T}}$. Examples of the three swimbladder conditions are illustrated in Fig.1.

One of the microsatellite loci, Labrax-13, was difficult to amplify in the multiplex system and 151 was excluded from the study. The remaining four loci allowed the unambiguous assignment of 264 152 out of the 273 genotyped offspring (97\%) to a single parental pair. The representation of the 
153 offspring in the different families and swimbladder conditions is given in Table 1., and the observed

154 and expected frequencies for each class are reported in Fig. 2. In both the normal and hyperinflated 155 group 23 of the 24 possible families were represented, whereas in the group without swimbladder only 22 families were found.

In larvae with normal swimbladder, the observed frequencies significantly differed from an expected random distribution, indicating differential survival both among half-sibling sire $\left(\chi^{2}=\right.$ 23.054; $P<0.001 ; d f=5)$ and dam $\left(\chi^{2}=9 ; P=0.0292 ; d f=3\right)$ families. In particular, survival of offspring generated from sire 5 and dam 2 was three-fold superior $\left(\chi^{2}=6.37 ; P=0.0116 ; d f=1\right)$ and two-fold superior $\left(\chi^{2}=4.35 ; P=0.0370 ; d f=1\right)$ to the other parents in the corresponding class, respectively. After correction for the survival frequencies observed in normal fish, larvae with noninflated swimbladder showed significant differences in family size only among half-sibling sire families $\left(\chi^{2}=38.557 ; P<0.0001 ; d f=5\right)$. Here, the number of larvae generated from sire 1,2 and 6 were two-fold superior to those of the remaining sires $\left(\chi^{2}=188 ; P<0.001 ; d f=1\right)$. In larvae with hyper-inflated swimbladder, imbalance in family size was found both among half-sibling sire $\left(\chi^{2}=\right.$ 37.082; $P<0.0001 ; d f=5)$ and dam $\left(\chi^{2}=24.21 ; P<0.0001 ; d f=3\right)$ families. Again, larvae from sire 1,2 and 6 accounted for more than twice those generated by the remaining male parents $\left(\chi^{2}=\right.$ 32; $P<0.001 ; d f=1$ ), whereas dam 1 and 4 produced 1.6 -fold more larvae than the other two females $\left(\chi^{2}=23.85 ; P<0.001 ; d f=1\right)$.

\section{Discussion}

In cultured fish considerable variation exists in the ability of larvae to achieve correct swimbladder inflation, and some species require adapted culture techniques. In the European sea bass, initial swimbladder inflation is size-mediated and usually occurs around the time of transition from yolk sac depletion to exogenous feeding, i.e. when the larvae measure on average 5.5 to 6.5 
swimbladder showed unequal survival at the end of the larval period, with the offspring generated from the best performing dam and sire each accounting for nearly $37 \%$ of the total. Imbalance in family size due to differential survival has been observed in this species by Garcia de Leon et al. (1998) using similar rearing conditions. These authors analyzed the performance of 9 sibling families in order to detect possible parental effects on various larval traits, including survival at 40dph, and reported up to two-fold variations in survival rates as a result of individual dam and sire effects. Parental influences on early survival of mass reared sea bass larvae were also observed by Saillant et al. (2001) using a larger crossing design. In their work, most of the parental effects on early survival were largely due to females or by the interaction between these and one particular male parent. This is also in agreement with our findings, where approximately $17 \%$ of the larvae with normally inflated swimbladder were siblings of the best performing female and male parent. Hence, all these results show that genetic components may be involved in the survival performance of sea bass larvae reared under communal conditions and that parental contributions are not simply additive but possibly interactive.

Failure to inflate the swimbladder is a major obstacle in hatchery-reared fish, and is generally regarded to result from the application of unsuitable culture practices though it has been reported occasionally in wild populations too (Egloff, 1996; Czesny et al., 2005). In the present work, sea bass larvae lacking functional swimbladders accounted for $3 \%$ of the total population at the end of the experimental phase (40 dph). Slightly higher rates (11\%) of larvae displaying non-inflated swimbladders at the same age have been reported by other authors (De León et al., 1998; Saillant et al., 2002). Our results highlighted a significant imbalance in family size due to paternal effects after correction for the survival frequencies observed in normally developed larvae. This is not in agreement with De León et al. (1998) who reported no significant parental effect for such an anomaly using a lower number of families but comparable rearing techniques. In a different genetic approach, Zilberg et al. (2004) found some alterations in transcription of genes involved in cardiovascular or muscular functions and associated with the state of swimbladder non-inflation in 
angel fish, Pterophyllum scalare (Cichlidae). These authors observed that this abnormal trait was accompanied by reduced expression of certain genes potentially causing the defect and increased transcription of others compensating for associated functional disorders. Even though the aetiology of swimbladder non-inflation was not clearly determined in angel fish, genomic alterations, environmental conditions or induced mutation were suggested as possible contributory factors.

Hyper-inflation of the swimbladder during larval stages is rarely cited despite causing considerable losses in some hatchery-reared species under improper culture conditions like gas hypersaturation and other stress-inducing factors, acting individually or in combination (Johnson and Katavic, 1984; Bagarinao and Kungvankij, 1986; Planas and Cunha, 1999). In cultured European sea bass, phenomena of hyper-inflation are largely controlled though occasional events are still observed in some experimental (Saillant et al., 2002) and commercial settings (Chatain and Peruzzi, pers. comm.). In all cases, the larvae show impeded swimming and feeding behaviour, float at the water surface and die of starvation within a few days. Our results would suggest that swimbladder hyper-inflation in sea bass, though predominantly influenced by environmental clues, might present a genetic basis for its expression too. In particular, this genetic component would involve both paternally and maternally inherited factors.

Overall, the results also suggest a possible correlation between the two anomalies regarding the sire effect, the same two male parents generating the bulk of larvae affected by non-inflation and hypertrophic conditions. Moreover, a better capacity to survive does not seem to correspond with an increased ability of achieving correct swimbladder inflation, as the best performing sire and dam do not appear to be those contributing less to both anomalies.

In this work, the relatively low number of larvae and families analyzed did not allow us to estimate full and half-sibling heritabilities of the observed swimbladder inflation conditions. Elsewhere, a study designed to estimate the heritability of the non-inflated swimbladder defect in striped bass, $M$. saxatilis, has shown a moderate genetic value $\left(h^{2}=0.35\right)$ for full-sibling families, and a low value $\left(h^{2}=0.04\right)$ for half-sib dam families (Harrell et al., 2002). As indicated by these 
231 authors, the half-sibling heritabilities showed scarce additive genetic variance for improvement of 232 this trait by selective breeding.

233 Although uninflated or hypertrophic swimbladders in sea bass are generally regarded to result 234 from the application of unsuitable culture conditions, our findings support the hypothesis of some 235 level of genetic influence associated with these defects too. If confirmed, this would point out an 236 even more complex co-causative mechanism of abnormal swimbladder development in this species. 237 Nevertheless, it is clear that the extent of genetic control over such traits can be further assessed 238 only using a dataset involving a larger number of families and individuals.

\section{Acknowledgements}

242 The authors would like to thank Marie-Odile Vidal, François Ruelle and Alain Vergnet for technical 243 support during experimentation. Marc Vandeputte (INRA, Jouy-en-Josas) is gratefully 244 acknowledged for his assistance with data analysis.

\section{References}

248 Alexander, R.M., 1966. Physical aspects of swimbladder function. Biological Reviews of the 249 Cambridge Philosophical Society 41, 141-176.

250 Bagarinao, T., Kungvankij, P., 1986. An incidence of swimbladder stress syndrome in hatcheryreared sea bass (Lates calcarifer) larvae. Aquaculture 51, 181-188.

Bailey, H.C., Doroshov, S.I., 1995. The duration of the interval associated successful inflation of the swimbladder in striped bass (Morone saxatilis). Aquaculture 131, 135-143.

254 Battaglene, S.C., Talbot, R.B., 1992. Induced spawning and larval rearing of snapper, Pagrus 255 auratus (Pisces: Sparidae), from Australian waters. New Zealand Journal of Marine and $256 \quad$ Freshwater Research 26, 179-183. 
257 Chapman, D.C., Hubert, W.A., Jackson, U.T., 1988a. Influence of access to air and of salinity on 258 gas bladder inflation in striped bass. Progressive Fish Culturist 50, 23-27.

259 Chapman, D.C., Jackson, U.T., Hubert, W., 1988b. Method for separating normal striped bass 260 larvae from those with uninflated gas bladders. Progressive Fish Culturist 50, 166-169.

261 Chatain, B., 1986. La vessie natatoire chez Dicentrarchus labrax et Sparus auratus. I. Aspects 262 morphologiques du développement. Aquaculture 53, 303-311.

263 Chatain, B., 1987. La vessie natatoire chez Dicentrarchus labrax et Sparus auratus. II. Influence 264 des anomalies de développement. Aquaculture 65, 175-181.

265 Chatain, B., 1994. Abnormal swimbladder development and lordosis in sea bass (Dicentrarchus 266 labrax) and sea bream (Sparus auratus). Aquaculture 119, 371-379.

267 Chatain, B., Dewavrin, G., 1989. Influence des anomalies de développement de la vessie natatoire 268 sur la mortalité de Dicentrarchus labrax au cours du sevrage. Aquaculture 78, 55-61.

269 Chatain, B., Ounais-Guschemann, N., 1990. Improved rate of initial swimbladder inflation in 270 intensively reared Sparus auratus. Aquaculture 84, 345-353.

271 Chatain, B., Corrao, D., 1992. A sorting method for eliminating fish larvae without functional $272 \quad$ swimbladders. Aquaculture 107, 81-88.

273 Chatain, B., Debas, L., Bourdillon, A., 1996. A photographic larval counting technique: comparison 274 with other methods, statistical appraisal of the procedure and practical use. Aquaculture 141, 8327596.

276 Ciftci, Y., Castilho, R., McAndrew, B.J., 2002. More polymorphic microsatellite markers in the 277 European sea bass (Dicentrarchus labrax L.). Molecular Ecology Notes 2 (4), 575-576.

278 Crespo, S., Marín de Mateo, M., Santamaría, C.A., Sala, R., Grau, A., Pastor, E., 2001. 279 Histopathological observations during larval rearing of common dentex, Dentex dentex L. 280 (Sparidae). Aquaculture 192, 121-132. 
281 Czesny, S.J., Graeb, B.D.S., Dettmers, J.M., 2005. Ecological consequences of swimbladder 282 noninflation for larval yellow perch. Transactions of the American Fisheries Society 134, 10112831020.

284 Dagnelie, P., 1975. Théorie et méthodes statistiques, vol II. Les Presses Agronomiques de 285 Gembloux, Belgium.

286 De León, F.J.G., Canonne, M., Quillet, E., Chatain, B., 1998. The application of microsatellite 287 markers to breeding programmes in the sea bass, Dicentrarchus labrax. Aquaculture 159, 303288316.

289 Divanach, P., Boglione, C., Menu, B., Koumoundouros, G., Kentouri, M., Cataudella, S., 1996. 290 Abnormalities in finfish mariculture: an overview of the problem, causes and solutions. In: 291 Chatain, B., Saroglia, M., Sweetman, J., Lavens, P. (Eds.), Seabass and Seabream Culture: 292 Problems and Prospects. European Aquaculture Society, Oostende, Belgium, pp. 45-66.

293 Divanach, P., Papandroulakis, N., Anastasiadis, P., Koumoundouros, G., Kentouri, M., 1997. Effect 294 of water currents during postlarval and nursery phase on the development of skeletal deformities 295 in sea bass (Dicentrarchus labrax L.) with functional swimbladder. Aquaculture 156, 145-155.

296 Duchesne, P., Godbout, M. H., Bernatchez, L., 2002. PAPA (package for the analysis of parental 297 allocation): a computer program for simulated and real parental allocation. Molecular Ecology $298 \quad$ Notes 2 (2), 191-193.

299 Egloff, M., 1996. Failure of swimbladder inflation of perch, Perca fluviatilis L. found in natural $300 \quad$ populations. Aquat. Sci. 58, 15-23.

301 Friedman, B.R., Shutty, K.M., 1999. Effect of timing of oil film removal and first feeding on 302 swimbladder inflation success among intensively cultured striped bass larvae. North American 303 Journal of Aquaculture 61, 43-46.

304 García de León, F.J., Canonne, M., Quillet, E., Bonhomme, F., Chatain, B., 1998. The application 305 of microsatellite markers to breeding programmes in the sea bass, Dicentrarchus labrax. $306 \quad$ Aquaculture 159, 303-316. 
307 Harrell, R.M., Van Heukelem, W., Jacobs, J.M., Schutz, J.R., 2002. Heritability of swimbladder 308 inflation in striped bass. North American Journal of Aquaculture 64, 117-121.

309 Jacquemond, F., 2004. Separated breeding of perch fingerlings (Perca fluviatilis L.) with and 310 without initial inflated swimbladder: comparison of swimbladder development, skeleton 311 conformation and growth performances. Aquaculture 239, 261-273.

312 Johnson, D.W., Katavic, I., 1984. Mortality, growth, and swimbladder stress syndrome of sea bass 313 (Dicentrarchus labrax) larvae under varied environmental conditions. Aquaculture 38, 67-78.

314 Kitajima, C., Watanabe, T., Tsukashima, Y., Fujita, S., 1994. Lordotic deformation and abnormal 315 development of swimbladders in some hatchery-bred marine physoclistous fish in Japan. Journal 316 of World Aquaculture Society 25, 64-77.

317 Martin-Robichaud, D.J., Peterson, R.H., 1998. Effects of light intensity, tank colour and 318 photoperiod on swimbladder inflation success in larval striped bass, Morone saxatilis (Walbaum). 319 Aquaculture Research 29, 539-547.

320 Marty, G.D., Hinton, D.E., Cech, J.J., 1995. Oxygen consumption by larval Japanese medaka with 321 inflated and uninflated swimbladders. Transactions of the American Fisheries Society 124, 623322 627.

Pelster, B., 1998. Buoyancy. In: Evans, D.H. (ed). The physiology of fishes, 2nd edn. CRC, Boca Raton, Fla.

Peruzzi, S., Chatain, B., 2000. Pressure and cold shock induction of meiotic gynogenesis and triploidy in the European sea bass, Dicentrarchus labrax L.: relative efficiency of methods and parental variability. Aquaculture 189, 23-37.

328 Peruzzi, S., Chatain, B., Saillant, E., Haffray, P., Menu, B., Falguière, J-C., 2004. Production of meiotic gynogenetic and triploid sea bass, Dicentrarchus labrax L.. 1. Performances, maturation and carcass quality. Aquaculture 230, 41-64.

Planas, M., Cunha, I., 1999. Larviculture of marine fish: problems and perspectives. Aquaculture 177, 171-190. 
333 Saillant, E., Chatain, B., Fostier, A., Przybyla, C., Fauvel, C., 2001. Parental influence on early 334 development in the European sea bass. Journal of Fish Biology 58, 1585-1600.

335 Saillant, E., Fostier, A., Haffray, P., Menu, B., Thimonier, J., Chatain, B., 2002. Temperature 336 effects and genotype-temperature interactions on sex determination in the European sea bass 337 (Dicentrarchus labrax L.). Journal of Experimental Zoology 292 (5), 494-505.

338 Sancristobal, M., Chevalet, C., 1997. Error tolerant parent identification from a finite set of 339 individuals. Genetical Research 70(1), 53-62.

340 Trotter, A.J., Pankhurst, P.M., Hart, P.R., 2001. Swimbladder malformation in hatchery-reared 341 striped trumpeter, Latris lineata (Latridae). Aquaculture 198, 41-54.

342 Trotter, A.J., Pankhurst, P.M., Morehead, D.T., Battaglene, S.C., 2003. Effects of temperature on 343 initial swimbladder inflation and related development in cultured striped trumpeter (Latris $344 \quad$ lineata) larvae. Aquaculture 221, 141-156.

345 Trotter, A.J., Pankhurst, P.M., Battaglene, S.C., 2005. A finite interval of initial swimbladder 346 inflation in Latris lineata revealed by sequential removal of water-surface films. Journal of Fish 347 Biology 67, 730-741.

348 Zilberg, D., Ofir, R., Rabinski, T., Diamant, A., 2004. Morphological and genetic characterization 349 of swimbladder non-inflation in angelfish Pterophyllum scalare (Cichlidae). Aquaculture 230, $350 \quad 13-27$. 
351 Legends

352

353 Table 1. Number of larvae with (a) normally inflated, (b) non-inflated, and (c) hyperinflated 354 swimbladder assigned to the 24 full-sibling families using the microsatellite loci Labrax-3, Labrax355 13, Labrax-17, and Labrax-29.

356

357 Fig.1. Photomicrographs of $20 \mathrm{dph}(7-8 \mathrm{~mm}$ TL) sea bass larvae with (a) normal functional 358 swimbladder, (b) hyper-inflated swimbladder, and (c) non-inflated swimbladder. Arrows indicate 359 the location of swimbladders. Scale bars represent $1 \mathrm{~mm}$.

361 Fig.2. Observed $(\square)$ and expected $(\square)$ numbers of larvae presenting normal (S ${ }^{+}$), non-inflated (S ) 362 or hyper-inflated $\left(\mathrm{S}^{++}\right)$swimbladders in paternal and maternal half-sibs. For non-inflated and hyper363 inflated groups, the expected frequencies represent weighted values. 


\begin{tabular}{cccccc}
\hline \multirow{2}{*}{ Sire } & \multicolumn{2}{c}{ Dam } & & 4 & Total \\
\cline { 2 - 6 } & 1 & 2 & 3 & 2 & 10 \\
\hline (a) normal & 3 & 3 & 2 & 4 & 11 \\
\hline 1 & 2 & 2 & 3 & 1 & 12 \\
\hline 2 & 2 & 6 & 3 & 0 & 9 \\
\hline 3 & 1 & 5 & 4 & 7 & 30 \\
\hline 4 & 5 & 14 & 5 & 3 & 11 \\
\hline 5 & 1 & 2 & 20 & 17 & 83 \\
\hline 6 & 14 & 32 & & & \\
\hline Total & & & & & \\
\hline
\end{tabular}

(b) non- inflated

\begin{tabular}{cccccc}
\hline 1 & 4 & 8 & 7 & 5 & 24 \\
\hline 2 & 6 & 6 & 5 & 6 & 23 \\
\hline 3 & 1 & 4 & 3 & 1 & 9 \\
\hline 4 & 0 & 3 & 1 & 0 & 4 \\
\hline 5 & 4 & 7 & 1 & 5 & 17 \\
\hline 6 & 4 & 5 & 4 & 4 & 17 \\
\hline Total & 19 & 33 & 21 & 21 & 94 \\
\hline
\end{tabular}

(c) hyperinflated

\begin{tabular}{cccccc}
\hline 1 & 4 & 4 & 3 & 5 & 16 \\
\hline 2 & 10 & 3 & 4 & 7 & 24 \\
\hline 3 & 2 & 4 & 0 & 2 & 8 \\
\hline 4 & 1 & 1 & 1 & 1 & 4 \\
\hline 5 & 5 & 6 & 2 & 6 & 19 \\
\hline 6 & 5 & 7 & 2 & 11 & 25 \\
\hline Total & 27 & 25 & 12 & 32 & 96 \\
\hline
\end{tabular}



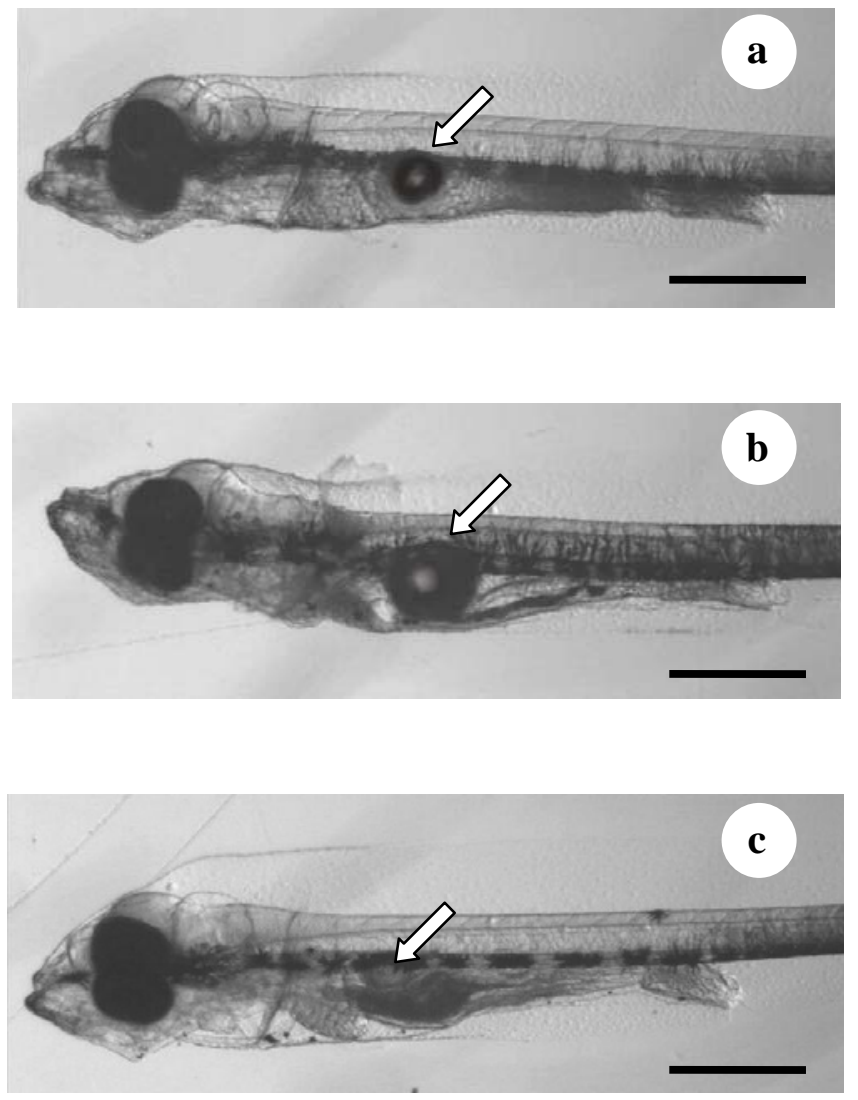

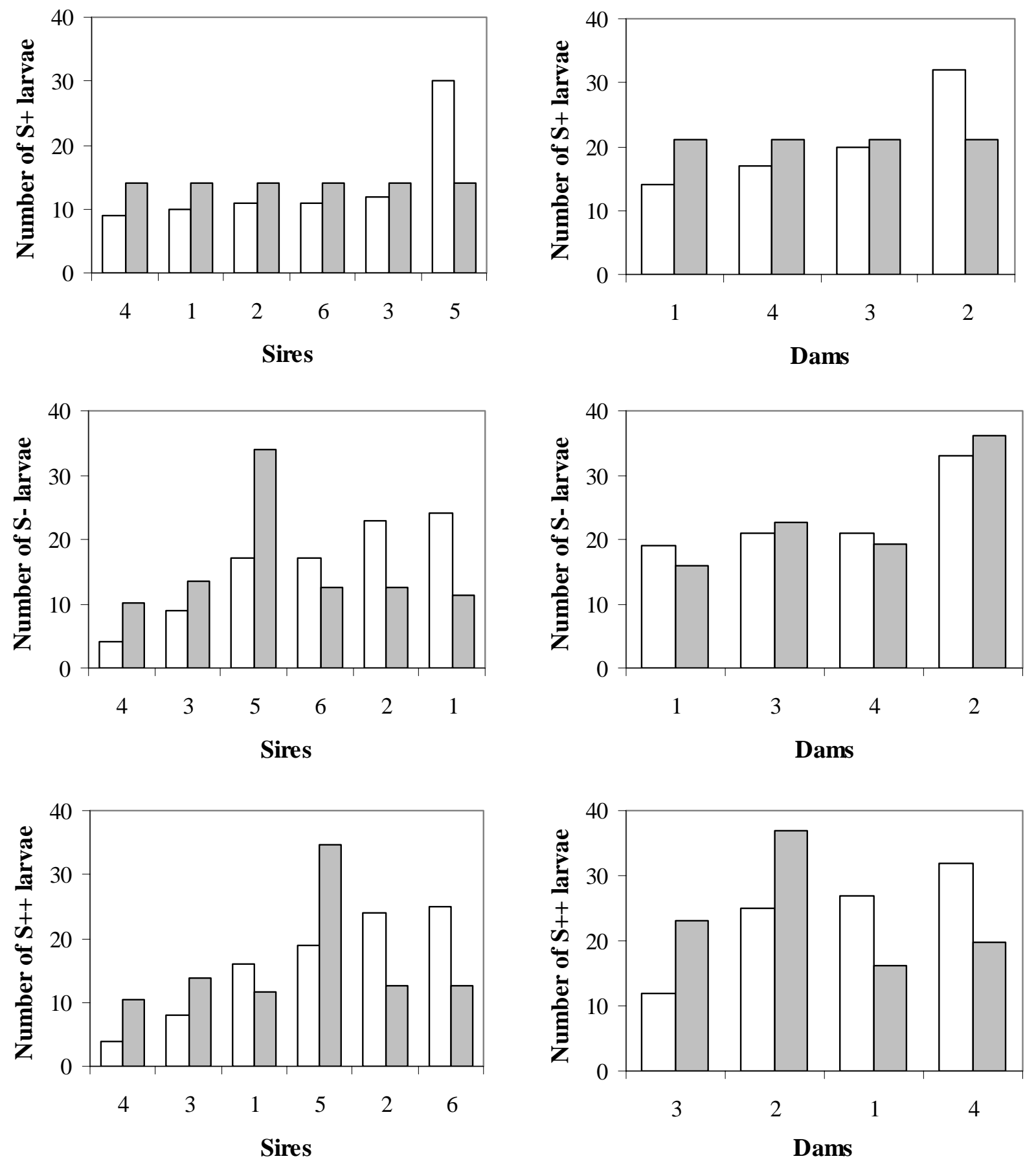